\title{
WAR YEARS DES MOINES M. E. CONFERENCE
}

\author{
By The Rev. R. E. HaRvey
}

III

\section{The New Conference ${ }^{1}$ Carried ON-1860-1864}

The first session of the Western Iowa Conference of the M. E. Church was held in Indianola, commencing Wednesday, August 22, 1869, at 8 o'clock a. m., Bishop E. S. Janes presiding. The bishop read the 131st and 133rd Psalms, inclusive; also the sixth chapter of 2nd Corinthians, after which hymn 707 was sung. The bishop then led the Conference in prayer, after which the sacrament of the Lord's Supper was administered by Dr. Elliott, assisted by Brothers Robinson, Stewart, Guylee and Haines. The roll of Conference was called by the Rev. E. H. Waring, the former secretary of the Iowa Conference, and twenty-nine members responded to their names. The Conference then organized by electing the Rev. E. M. H. Fleming as secretary, and the Rev. C. C. Mabee and $\mathrm{D}$. Thompson as assistant secretaries.

So reads the upper half of page one of my tattered copy of the pamphlet titled as on the first line above. Follows three and one half pages of committee lists, minute business, appointments, official announcements; eighteen of committee reports, and four of advertisements.

Next to the moment of listening to their assignments to their various fields of labor, it is probable that the most intense interest of the entire session was elicited by the report on "Our boundary lines," voicing dissatisfaction with the departure from the instructions voted by Iowa Conference the previous year, ${ }^{2}$ by the recent General Conference, whereby the line dividing their territory from

\footnotetext{
ISee ANNALS of IowA, for January and April, 1944, for story of foundation laying of the M. E. church in the territory comprising the old Des Moines Conference.

'See AnNal, of Iowa, April, 1944, p. 297-298.
} 
that of Iowa Conference was so diverted that it followed Des Moines river from Red Rock to the south line of Boone county, depriving the new Conference of portions of Marion, Jasper and Polk counties containing several prosperous parishes, in the longest settled-sector of their expected area, which even without this loss would have consisted of two thinly peopled belts along its east and west borders, separated by one hundred miles of open prairie, which for lack of navigable streams then seemed doomed to a very scattering population.

This alteration of the boundary the report denounced in no uncertain terms, as due to the influence of the Iowa Conference delegates (all of whom came from east of the dividing line), who were accused of acting in a "discourteous, unfraternal, and unjust manner toward the proposed Western Iowa Conference," by which "a confiding and defenseless portion of their constituency have been grievously wronged"; for which "abuse of a most sacred official trust" it was hoped they would be suitably rebuked by the mother Conference, that was exhorted to join with the injured body in securing redress of these wrongs at the next session of the governing body of the Church. The verbiage of the entire document hinting to one who knew him, the urge felt by the Rev. U. P. Golliday, the chairman of the committee drafting the report, to revert to the robust vocabulary of his youthful flatboating days on the Ohio.

This production was transmitted to Oskaloosa, where Iowa Conference met the next week, along with a proposal that the two bodies ignore the obnoxious legislation and administer the disputed territory according to their original intentions, ${ }^{3}$ action which would have been completely subversive of denominational polity; while the recommended censure of five of their most prominent members was most unlikely procedure to promote sacrificial response in those who would profit by their depar-

3See History of Iowa Conference, by the Rev, E. H. Waring, p.p. 157-158. 
ture from the letter of their instructions; so the Iowa Conference brethren, while deploring the wounded feelings of their former colleagues, didn't see just what could be done about it.

Indeed, the members of the new unit may have felt their old associates entertained some designs of retaining the new body attached to mother's apron strings, since here was the president of Iowa Wesleyan University with a proposition that western lowa pledge financial and other support to that institution, offering as inducements representation on the board of trustees, and the transfer of a faculty member to their Conference roll. But the committee on education, with four projects of their own to consider, cautiously refrained from other commitments than that of directing college minded youth toward Iowa Wesleyan, and of cordially inviting Dr. Elliott himself to become one of them! Now, although the name of that most eminent educator, pulpit orator, church statesman and religious journalist, graced more than one Conference roll, neither Western Iowa nor Des Moines Conference ever enjoyed that distinction, though we find him renewing his plea for co-operation with Iowa Wesleyan about as long as he was connected with that institution.

With their own educational fish to fry, the committee proceeded to deal with them in a manner best reported by reproducing the resolutions relating to each project with brief account of the same.

\section{BROOKVILLE SEMINARY}

"Resolved: That we will accept Brookville Seminary and give it our fostering care, as soon as the building may be completed, free from debt, and the school put in operation." Probably few even of the present residents of Brooks village ever heard of this institution; and the names of the original sponsors we have been unable to find. The enterprise took shape apparently in the year 1859-60, and Rev. James S. Rand was appointed at this 
session as Pastor of Quincy Circuit, covering most if not all of Adams county, perhaps in hope that his energetic complex might give vigor to the undertaking. In 1861 the name was changed to Simpson Seminary, and a Board of Visitors appointed, who in 1862 reported that a two story building was enclosed and one room finished and in use by the district school, and that though war excitement and financial stress barred immediate progress, the prospects for completion and usefulness were considered good; with which the institution sinks out of sight. The building when completed was taken over for public school use and may still be standing, as it was framed of native lumber, in providing and delivering which, according to local tradition, a certain eccentric local preacher seriously neglected farm and family, and on the failure of the undertaking, became an unreasoning opponent of ministerial education: that he was the latter I can testify, for he was a parishioner on my first Supply Circuit.

\section{OSCEOLA SEMINARY}

"In view of the fact that the citizens of Osceola have determined to establish a seminary at that point and desire to place it under the care of this Conference, and desire to open a school immediately, we offer the following resolution for your adoption:

Resolved: 1st, That R. S. Robinson, F. H. Read and Michael Sheets be a committee of visitors to attend the annual examination of Osceola Seminary, and to report its condition and prospects to this Conference at its next session. 2nd, That as soon as a suitable building, worth at least $\$ 3,000.00$ shall be erected for said seminary, free from pecuniary embarrassment and ready for use, we will extend to it the privileges and favors of a Conference Seminary."

This report was re-affirmed the following year, the visiting board continued, while a half page advertisement announced the opening of the second term on Sept. 23, 
1861, with Prof. H. B. Heacock, superintendent; promising cheap and abundant accommodations in room and board; adding, "The success of this institution the past year, and the deep interest taken in the cause of education by the people of Osceola and Clarke county warrant the trustees in proceeding with their efforts to make this institution a fixed fact in the educational department of Iowa." Both visitors and advertisement re-appeared in 1862 , H. B. Heacock was admitted on trial by the Conference and appointed Principal of Osceola Seminary. In 1863 the school was declared prosperous and out of debt, and recommended to the people of southwest Iowa generally, while H. B. Heacock was appointed pastor of Osceola charge, without indicating whether he combined ministerial with pedagogical duties, although this was a frequent practice at that time. 1864 found him moved to Chariton, and Osceola Seminary appears no more.

\section{COLUMBUS SEMINARY ${ }^{4}$}

Like fate befell this institution which the session of 1860 endeavored to revivify by continuing Louden District with the Rev. Wm. H. Goode, as presiding elder, who was made also chairman of a new board of trustees in which several adjacent ministers were colleagues along with Messrs. Claiborne and Pitzer, laymen. Both district and station were left off the rolls in 1861, and U. P. Golliday was directed to "inquire into the condition of Columbus Seminary and report at the next session," which report stated that the seminary was incorporated subject to Iowa Conference authority and had never been legally transferred to Western Iowa; whereupon the foregoing election of trustees was rescinded, and R. S. Robinson made agent to adjust matters with Iowa Conference, to which body the agent was transferred during the ensuing year, and no mention of his agency ever appeared in either Conference journal. A sort of post-mortem of this ill-

${ }^{4}$ See Annals of Iowa, April, 1944, pp. 294-295. 
starred enterprise appeared very recently ${ }^{5}$ in a history of Tabor College: "In 1867 doors and window frames were purchased from the tornado wrecked building of Columbus University, eight miles north of Tabor." The Rev. John S. Guylee, chief promoter of this exploded vision, entered the U. S. Army in 1861 as 1st lieutenant, Company A, 4th Iowa Cavalry; rendering such efficient service that he was promoted successively to captain, major, and in 1864, was made colonel of an Arkansas negro regiment, but sad to relate, descended in the moral scale faster than he rose in military rank, fell into grievous sin, was located by the Conference at the 1862 session, and so vanishes without a trace. A better finale awaited his colleague in the ministry, seminary project and army life, the Rev. John M. Rust, ${ }^{6}$ who also shared his moral shipwreck, but came before the Conference making frank confession, professed sincere repentence and the assurance of complete forgiveness and was restored to ecclesiastical rank as an ordained local preacher and in 1868 was employed by the Rev. Bennett Mitchell, then presiding elder of Chariton District, to supply La Grange charge. Going to Sioux City District the next year, Elder Mitchell took Bro. Rust with him to supply Onawa Mission, where his work won restoration to Conference membership and appointment to Vermillion, Dakota Territory, and there he ended his earthly career, restored we trust to the favor of God as well as the Church. ${ }^{7}$

\section{INDIANOLA MALE AND Female SEMINARY}

A better destiny awaited this institution, to which the Conference recommended diligent prosecution of their undertaking; pledging patronage upon the completion of a $\$ 3,000.00$ building free of debt; confirmed a board of

\footnotetext{
"See Iowa Journal of History and Politics, October, 1943, Article "Tabor College," by Catherine Grace Barbour Farquhar.

See ANNALS OF IoWA, April, 1944, pp. 300-301. The additional information concerning J. M. Rust given here was unearthed since publication of previous articles; and some additional light on various other episodes also has been re-
ceived.

${ }^{7}$ See History of N.W. Iowa Conference, by Bennett Mitchell
} 
eleven lay trustees, to whom they added the Reverends S. S. Haines, E. M. H. Fleming, E. H. Winans, E. Wood, H. H. Badley and R. S. Robinson; of whom the first three were directed "to visit the school; should one be established and report to the next Conference." That the school was established promptly appears from a full page advertisement that sheds interesting light on educational ideals and living costs in that year of grace 1860.

The first term of the Indianola Male and Female Seminary will commence the 24 of September, 1860, under the superintendance of Professor Gray, formerly of Iowa Wesleyan University. The price of tuition will range from $\$ 3.00$ to $\$ 8.00$ per term of twelve weeks, according to the branches studied. For specific terms see the principal. Music and modern languages extra. It will be to the advantage of students to be in attendance at the opening of the session, but in case any are hindered, they will be welcome and provided for. Teachers desiring to prepare themselves better for their work will find in this institution every facility to aid them in their noble purpose, as special attention will be given to the subject of normal Instruction. Boarding may be had at $\$ 1.50$ to $\$ 2.00$ per week.

E. M. H. Fleming, President of the Board.

N. B. Brethren of the ministry will please call the attention of our people and friends to this excellent opportunity of obtaining a good education for their sons and daughters, and so much the more, that this is the first institution in actual operation within the bounds and under the patronage of our noble young Conference. E. M. H. F.

As it was the first seat of learning in this territory, so it proved the last of many such to survive, and after eighty-five eventful years continues to flourish, with every present prospect of outlasting another such era.

On page 5, Minutes of 1863 appears mention of the reference to the committee on education of papers relating to Pleasant Plains College, which that body refused to consider. Of two places so named in those early records, one in Decatur and the other in Marion county, the latter seems to us the most likely location for this ambitious project to extend the range of human knowledge. 
A prior gesture to all of these attempts may be found in the Iowa Conference Journal for 1856, where approval was expressed and trustees elected for Des Moines Male and Female Seminary, of which no further notice appears. Neither did any of our city historians ever seem to have heard of it; leaving it fair to infer that this probably was one of the bright blossoms springing up in that boom year, only to be blighted in the panic of 1857 a catastrophe that engulfed Fifth Street Church in bankruptcy so completely that for almost a decade they enjoyed only partial use of their property, and that by grace of generous creditors. And we will encounter still other like tragic tales as we proceed further.

Returning to the Western Iowa session of 1860 , we find the Conference organizing itself as a missionary society; re-enacting an Iowa Conference financial plan, an elaborate affair that would have demanded the services of a full time manager on every circuit; adopting resolutions framed by committees on tract distribution, church periodicals and such like interests, too complicated for transposing into action in the primitive conditions then existing, save for that on temperance, which might well serve as a perpetual model for all such utterances.

"Resolved, That this Conference has unshaken confidence in the great temperance reform, and that we will in all suitable ways and by all lawful means, work to carry forward this great cause, and we will heartily cooperate with all good men in this work. H. H. Badley, J. S. Rand, Comm."

\section{Financing In Depression Years}

The statistical tables represent 37 stations and circuits, reporting 4,436 full members, 1,251 probationers, 22 local preachers. Twenty-eight churches, valued at $\$ 29,200.00$; and fourteen parsonages worth $\$ 6,475.00$; the investment in future growth consisted of 126 Sunday schools, costing $\$ 555.16$, and having an enrollment of 6,319 of all 
grades, on which dividends had been realized of Sixtysix conversions amongst the pupils.

Figures for pastoral support range thus: Des Moines, $\$ 614.00$; Council Bluffs, $\$ 550.00$; Buena Vista $\$ 539.00$; Indianola $\$ 532.00$; Magnolia, $\$ 530.00$; Hartford, Sidney Bedford, $\$ 500.00$ each; seven charges scaled downward from $\$ 460.00$ to $\$ 300.00$; twenty-two were below that, the lowest being $\$ 106.25$. This however was merely salaries pledged; salaries paid was a horse of another color; four parishes only constituted the honor roll of paid in full ; Indianola, Afton, Oceola, and Montgomery Mission; the Fifth Street, Des Moines pastor sustained a deficit of $\$ 211.00$; presumably still in default; the Conference averaged 68 per cent of claims paid: demonstrating clearly that while depression as related to financial affairs was an unknown word, the fact and experience are not recent discoveries.

When we realize that these salaries were pledged at a time when common labor rated 25 cents per diem; skilled workmen drew $\$ 1.00$ per day, and school teachers throve on $\$ 10$ to $\$ 25$ per month, it is evident the Iowa Methodists meant well by their ministers; doing well was beyond the power of many. $\$ 1,000.00$ granted by the General Mission Board to supplement local support was allocated thus, with what measure of equity none can now declare. One half went to the presiding elders of Chariton, Louden and Council Bluffs districts; $\$ 200$ to the pastor at Council Bluffs; $\$ 50$ each to those at Adair, Harlan, Quincy, Clarinda and Louden; $\$ 25$ each to Hopeville and LaGrange. The official summary of business transacted may stir up regrets among preachers who wrestle with the twentieth century gigantic Conference agenda that the age of simple duties and responsibilities is gone, never to return.

\section{DISCIPLINARY QUESTIONS}

1. Who are admitted on trial? Ans. H. H. O'Neal, Oliver Williams, J. T. Hughes, Henry Gardner, M. H. Martin, and J. Levan.-6 
2. Who remain on trial? Ans. J. B. Tallmadge, G. S. Nicholas, C. C. Mabee and J. Cowger.-4

3. Who have been admitted into full membership? Ans. J. M. Conrad.-1

4. Who are the deacons? Ans. J. W. Todd, B. Shinn, A. H. Murphy; ordained this year, J. M. Conrad.-4

5. Who have been elected and ordained elders? Ans. Jacob Delay, John M. Baker, Calvin Spooner and Dugald Thompson.-4

6. Who have located this year? Ans. W. Howbart, J. B. Rawls and J. B. Peterson.-3

7. Who are the superannuated preachers? Ans. D. N. Smith, D. Dickinson, T. M. Goodfellow and D. H. Petefish.-4

8. Who have been expelled from the connection this year? Ans.None

9. Who have withdrawn from the connection this year? Ans.None

10. Are all the preachers blameless in life and conversation? Ans. This was carefully attended to by calling over their names before the Conference.

11. Who have died this year? Ans. None

12. What is the number of church members etc? Ans. See statistical tables.

13. What amounts are necessary for the support of superannuated preachers, widows and orphans of preachers, and to make up the deficiencies of those who have not received their regular allowances on the Circuits? Ans. Not reported.

14. What has been collected on the foregoing and how has it been applied? Ans. From circuits and stations; $\$ 17.25$; From chartered fund, $\$ 25.00$; total $\$ 42.25$. The above has been appropriated as follows: To the Rev. D. Dickinson, $\$ 25.00$; to the Rev. T. M. Goodfellow, $\$ 17.25$. Total, $\$ 42.25$.

15. What has been contributed for the support of missions? What for the Sunday School Union? What for the publication and distribution of tracts? And what to aid the American Bible Society? Ans. For missions, $\$ 357.39$; for Sunday School Union, $\$ 3.83$; for tracts, $\$ 1.20$; for Bible Society, $\$ 42.25$; Total, \$404.17.

16. Where are the preachers stationed this year? Answer.

Des Moines District-Sanford Haines, Presiding Elder; Des Moines, E. H. Winans; Indianola, E. M. H. Fleming; Hartford, E. H. Martin, one to be supplied; Wheeling, Thos. Dixon; Newbern, John W. Anderson; New Virginia, Enoch Wood; Winterset, U. P. Golliday; Brooklyn,* J. M. Baker; Adel, H. H. Badley, D. Thompson; Lawrenceburgh, A. H. Murphy; Xenia, G. S. Nicholas.

*A long vanished village in Madison county. 
Chariton District-R. S. Robinson, Presiding Elder; Chariton, Joseph Knotts; Hopeville, J. B. Tallmadge; Osceola, F. H. Read; New York, Jesse Sherwood; Garden Grove, C. C. Mabee; LaGrange, To be supplied; Mt. Ayr, B. Shinn, J. T. Hughes; Afton, Michael Sheets; Decatur City, Henry Gardner; Corydon, Jacob DeLay; Leon, B. F. Williams; Liberty, to be supplied.

Louden District-Wm. H. Goode, Presiding Elder; Louden, J. W. Todd; Sidney, John Guylee; Red Oak, Oliver Williams; Clarinda, C. Woolsey; Bedford, Bennett Mitchell; Hawleyville, J. M. Rust; Quincy, James Cowger.

Council Bluffs District-Arthus Badley, Presiding Elder; Council Bluffs, J. F. Goolman; Magnolia, S. Farlow; Buena Vista, D. B. Clary; Harlan, To be supplied; Panora, J. M. Conrad; Guthrie Center, To be supplied; Adair, Jacob Levan; Lewis \& Audubon, C. F. Spooner.

I. I. Stewart, E. H. Waring, E. T. Coiner, transferred to Iowa Conference.

In the foregoing list of appointments, Xenia, long since vanished, a hamlet one mile east of Woodward, replaced Beaver Circuit, and Red Oak takes the place of Montgomery Mission. Guthrie Center appears for the first time on the roll being detached from Panora Circuit along with a dozen or more preaching places in the western and southern portion of Guthrie County. Liberty is possibly Liberty Center in Warren county later replaced by New Virginia after the building of the railroad. Of the local preachers used as supplies we can name but one, the Rev. Kirtland Card who supplied Harlan as he had done the preceding year, ${ }^{8}$ and so acceptably that in 1861 he was admitted to Conference on trial.

This exhibit shows that the area served was occupied by one or more parishes in each county, most of. which were circuits including four to a dozen points, visited by the pastor every two to four weeks according to their extent, while on the intervening Sabbaths, class meetings took the place of public worship, held by the leaders, ${ }^{9}$ a

\footnotetext{
${ }^{8}$ See History and Biography of Shelby Co., W. E. Sumner \& Co., Chicago, 1889.

'The class leader was a devout layman, who did much of the pastoral visiting on those far flung circuits and met his flock each week in gatherings for song, prayer, the relation of experiences and inquiry into their spiritual progress.
} 
potent means of spiritual growth amongst early Methodists, but long since dropped as ministerial services multiplied.

\section{War Works Havoc With SOME Ministers}

During its one quadrennium of existence Western Iowa Conference experienced little alteration from the above exhibit except from change of circuit titles and shift of district boundaries; most important of the latter was the substitution of Council Bluffs for Louden as head of the southwestern district, and the placing of the charges attached above to Council Bluffs, along with Quincy \& Simpson Circuit, in Lewis District. The membership remained about static, and but slight material progress was recorded, since both private and public interest was absorbed by the struggle for the preservation of the Union, into which both ministry and laity threw themselves unreservedly. The minutes of 1862 listed by charges 454 members who had gone to the army, adding that complete reports would doubtless show at least 500 as so engaged. Every copy of the Conference journal for those hectic years contains ringing resolutions in support of the national government and the Stars and Stripes were unfurled over every meeting place.

Nor did the preachers confine themselves to lip service, merely. Mention has already been made of two who, going out as officers, became moral casualties, and there were those who even in the chaplaincy seemed to find army life a spiritual detriment, for they came not back into ministerial pursuits. One such was T. M. Goodfellow, who served two years as chaplain of the famous "Fighting Fourth Iowa," and then was located by the Conference and is lost to sight. Another was the aggressive James S. Rand, who as pastor of Frankfort Circuit (formerly Montgomery Mission), demonstrated his patriotism by reading out of the church certain laymen suspected 
of disloyalty to the Union cause. ${ }^{10}$ Later on he enlisted as a recruit in the Fourth Iowa Infantry, then was promoted to chaplain of the First Iowa Cavalry, with which command he served until it was mustered out in 1866 ; but his only connection with the church thereafter consists of his name in the local preachers list of Council Bluffs District, with no trace of any employment in the ministry even as supply pastor.

But there were others: David N. Smith, despite infirmities that kept him out of the pulpit most of his life, enlisted as captain in the 28th Iowa Infantry, was two days later made regimental chaplain; discharged for health reasons in six months and then assuming charge of Fifth Street Church, extricated it from beneath the mountainous debt that had confined its worshippers to the basement for several years, while the mortgagees rented the upper story for secular and amusement purposes, but to do them justice, relinquished a considerable part of their claim to aid in the debt raising. The Rev. Mr. Smith performed further services for western Iowa Methodism that will be noted more fully.

The Rev. John M. Conrad leaving Magnolia Circuit, accompanied the 29th Iowa Infantry to the front, serving its spiritual interests as faithfully as ever any parish in peacetimes. At the age of 50, the Rev. Uri P. Golliday gave a year of like assistance to the men of the 14th Iowa Infantry, and then resigned because those in command refused or neglected to heed his earnest exhortations that they give their soldiers protection from the purveyors of vice and drunkenness.

The Rev. Charles S. Jones was chaplain of the 8 th Iowa Cavalry when change of boundaries in 1864 made him a member of Des Moines Conference. On return of peace he served Iowa Falls charge for two years and then was

\footnotetext{
${ }^{10}$ Authority for this episode is Brother John H. Murray, one of the "read outs"a native of Tennessee whose sympathies with his native southland were very pronounced. He was reinstated in the church at the close of the war through the efforts of the Rev. U. P. Golliday.
} 
located for unstated reasons. Still others who subsequently transferred to Des Moines Conference gave chaplain service while attached elsewhere, but enough has been given to prove that western Iowa ministers earned their fair share of the encomiums bestowed by Abraham Lincoln upon the Methodist Episcopal Church. ${ }^{11}$

And space will not permit due appreciation of the laymen soldiers among whom this writer grew up, listening to their tales of pain and peril with envious regret that life had not cast my lot in the years of their trials and triumphs, and from whom a maturing mind absorbed the patriotism that impelled them to take up arms in freedom's cause. For two-thirds of my active ministry the G. A. R. button featured every congregation, appeared in almost every official gathering; at their firesides oft times religious conversation turned upon the prayer meetings under shell fire, in trenches about Vicksburg and Mobile in which earnest souls found at the Throne of Grace the morale needed to storm the enemy lines on the morrow.

With rare exceptions these warriors were loyal to their church, their pastor and their God; graciously tolerant of youthful inexperience and highly appreciative of my interest in their heroic past. And it would be ungrateful to by-pass a few champions of the "Lost Cause" who had drifted North, buried past animosities, renewed their devotion to our common country, and joined hands with ancient antagonists in building the walls of Zion, as well as promoting the general prosperity.

Nor can I forget that large but ever lessening group of brother ministers who, once soldiers of Uncle Sam, became soldiers of the Cross before me; their kindly welcome to the raw recruit in the Wars of the Lord; their understanding and encouragements, derived without much question from their own long past experiences,

\footnotetext{
11See the official Roster and Record of Iowa Soldiers in the War of the Rebellion, 1910 , for all items connected with military services rendered by those here
mentioned.
} 
kindled a glow still warm in my heart, though they have long ago pitched their tents on Fame's eternal camping grounds.

Compensation for the ministerial casualties mentioned above came to western Iowa in various ways. The Rev. Joseph Sullivan, local preacher founder of Lineville Methodism, ${ }^{12}$ in 1863 was received as a local elder from the M. E. Church South, and a large number of his coworshipers came along with him. The next year came from the same source a more noted name, the Rev. William C. Martin, who while still in the local ranks served Boone county as superintendent of schools and representative in the legislature. Entering the itinerancy, he filled some of the most important pastoral appointments, was twice presiding elder, twice delegate in the General Conference, and in retirement wrote a history of Warren county from which much has been gleaned for these articles.

More impressive at the time was the transfer of the presiding elder of Kanawha District, West Virginia Conference, the Rev. George J. Nixon, who, driven from there by disunion elements, first supplied Garden Grove when the pastor, U. P. Golliday went to the army; then was stationed at Winterset and like places until vocal failure, due to early misuse in camp meeting efforts of a one time powerful voice, compelled retirement. His tall rangy frame with its white crown of glory was a notable sight at any Conference; his last participation in debate was a successful argument against restoration of the parchments of a one time minister who had been deposed for gross immorality, George Nixon's clinching appeal remains indelibly impressed on memory's tablets: "This brother claims to have repented and been forgiven; I do not question the infinite mercy of God, even to the vilest of sinners, but this Conference owes its own good name

\footnotetext{
${ }^{12}$ See AnNals of IowA, January, 1944, pp. 195-196.
} 
such action as will demonstrate that some sins are regarded as unpardonable in a minister of the Gospel."

\section{Growth Under Trying CoNditions}

Despite war's alarms and demands, the church registered some advance during those fateful years. Missionary contributions, stimulated by publishing givers and gifts in the Conference Journals by districts and parishes, increased 700 per cent in two years, and these exhibits have laid the historian under everlasting obligation for preserving long forgotten names of circuits, classes and individuals: And the four districts reported in 1864 fortytwo churches and twenty-eight parsonages, valued respectively at $\$ 50,000$ and $\$ 14,250 ; 6,693$ communicants; 157 Sunday schools having 8,376 attendants. In this showing however must be included material and spiritual assets from six pastoral charges in the "Lost Province" east and north of Des Moines river, restored in May, 1864, of which more in the next section.

Having noted ministers coming from the South in the war years, we now give some appraisal of those received on trial by Western Iowa Conference.

In 1860 Henry H. O'Neal headed the class for admission with gifts and talents which won prominence from the start, as evidenced by his roster of appointments, viz: Glenwood, Sidney, Council Bluffs, Onawa, Sioux City, Winterset, Chariton, Wesley chapel (Des Moines), Red Oak, Corning, presiding elder, Corning District, 4 years, Clarinda and founder-pastor Trinity church, Des Moines. He was also General Conference delegate in 1884, and member of the General Mission Board 1884-88. Along with his son Ernest, Dr. O'Neal transferred to an Illinois Conference, where both ended their labors and lives.

Jeremiah T. Hughes, admitted at the same time, has already been mentioned. We will add that after some years of pioneer work he settled on a farm near Conway, Taylor county (understood at the insistence of his fam- 
ily), and until superannuated served such circuits as could be reached from there. Few save professional land surveyors left more footprints over southwestern Iowa than did this self-styled "circuit walker," whose parish once covered three entire counties, around which he tramped every three weeks, preaching in the county capitals on Sundays and countless other points week days and nights. Today no fewer than twenty Methodist pastors devote full time care to churches flourishing in the area that he once trod alone. Quaint, crude, kind, good "Uncle Jerry"! He received this writer, aged nine, into the church, and prayed that God would make a minister of me.

1861 brought Geo. P. Bennett and William Abraham, of whom the former mounting the ladder round by round became presiding elder, and then went to the Pacific coast and there concluded his earthly career. Bro. Abraham, slight in figure, precise in diction, English in nativity and temperament, did yeoman service on a long list of minor charges, the axe and spade work from which arose churches large and small. He was for many years assistant secretary, and from him I acquired by honorable purchase the file of minutes, without which I would never have attained historian rank.

1861 also brought to western Iowa by transfer Samuel Jones, who, converted in early manhood under the ministry of William Taylor, later a world famous evangelist and missionary bishop in Africa, partook of that master soul's passion for other souls. By ten years as "supply pastor" and six years in the regular ministry he acquired training for frontier leadership and here by twenty-one years of faithful endeavor, four of them as presiding elder of Boonesboro District, he laid sure and firm foundations whereon others built. Even after superannuation he supplied various charges, conducting revivals everywhere and giving constructive direction in wiping out 
debts and erecting buildings, of which twenty churches and six parsonages arose as monuments to his memory. With salaries averaging $\$ 400.00$ for the years of his active labors, and never above $\$ 850.00$, he managed to live within his means, never leaving an unpaid bill, and gave his children a good education. "He was a pure, gentle, earnest man, loyally devoted to the church of his choice, and justly held in esteem in the community in which he lived and died."

Of others received on trial or by transfer in this quadrennium we make no note, their stay in Iowa being too brief to identify them with our church life.

\section{A Mutual Protection Society}

Moved thereto by the first death in its ranks Western Iowa Conference at this 1864 session organized itself into a mutual aid society, in which each member pledged himself to raise or give $\$ 10.00$ for the relief of Mrs. Chas. Woolsey, widow of the deceased brother, and a like sum upon every succeeding decease. And we close this section of our chronicle with brief reference to the one sole surviving educational undertaking, Indianola Male and Female Seminary. The committee on education gave it flattering notice and commendation for the excellent work being done; urged the trustees to enlarge its facilities both in buildings and equipment as essential to its continuation, and then lamented that with laymembership of six thousand, there were not more seats of learning within their bounds. To remedy this situation they exhorted presiding elders and pastors on the northern and western borders of the newly extended Conference territory to be on the alert to locate and secure suitable sites for future planting of seminaries and colleges. From this resulted much wasted endeavor and frustrated hope in years to come. 
Copyright of Annals of Iowa is the property of State of Iowa, by \& through the State Historical Society of Iowa and its content may not be copied or emailed to multiple sites or posted to a listserv without the copyright holder's express written permission. However, users may print, download, or email articles for individual use. 